\title{
RNA Metabolism of Rhodopseudomonas spheroides during Preferential Photopigment Synthesis
}

\author{
By T. G. LESSIE* \\ Microbiology Unit, Department of Biochemistry, University of Oxford
}

(Received 4. January 1965)

\begin{abstract}
SUMMARY
During anaerobic growth of Rhodopseudomonas spheroides the specific RNA content ( $\mu \mathrm{g}$. RNA/ $\mu \mathrm{g}$. protein) of cultures was directly proportional to the light intensity in which they were grown. Cultures subjected to a step-up in light intensity preferentially synthesized RNA until their specific RNA content increased to the value characteristic of growth at the higher light intensity. Conversely following a step-down in light intensity the rate of RNA synthesis fell below the rate of protein synthesis, and cellular RNA was diluted out to the value characteristic of growth at the lower light intensity. Adjustment of the differential rate of RNA synthesis in response to a change in light intensity was thus opposite to that of the differential rate of photopigment synthesis. Although a decrease in light intensity drastically decreased RNA synthesis some RNA continued to be formed. The RNA synthesized, like that in cultures maintained at a constant light intensity, consisted of soluble and ribosomal RNA and unstable RNA with sedimentation behaviour like mRNA. Aerobic cultures of $R$. spheroides subjected to a marked decrease in $\mathrm{O}_{2}$ tension synthesized photopigments de novo without appreciably increasing their net content of RNA, but continued to synthesize small amounts of all the usual classes of RNA.
\end{abstract}

\section{INTRODUCTION}

Rhodopseudomonas spheroides when grown aerobically is devoid of bacteriochlorophyll and contains only traces of carotenoids, but it synthesizes large amounts of these photopigments when grown anaerobically in the light or when incubated semi-aerobically in the dark (Cohen-Bazire, Sistrom \& Stanier, 1957). The extent of pigment formation is inversely proportional to light intensity or to the $\mathrm{O}_{2}$ tension under semi-aerobic conditions. Formation of bacteriochlorophyll is strictly dependent upon protein synthesis (Sistrom, 1963; Bull \& Lascelles, 1963). This is in part explained by the fact that certain enzymic activities associated with bacteriochlorophyll formation increase in parallel with the ability to form photopigments (Lascelles, 1959; Gibson, Neuberger \& Tait, 1963). However, the obligatory requirement for protein synthesis in already pigmented cultures, which presumably contain all the enzymes necessary for bacteriochlorophyll synthesis, suggests that bacteriochlorophyll formation must proceed with joint synthesis of some protein component of the photosynthetic apparatus. Evidence that proliferation of intracellular membranes is concomitant with development of photopigments in the Athiorhodoaceae

* Present address: Department of Biological Sciences, Purdue University, Lafayette, Indiana, U.S.A. 
supports this view (Cohen-Bazire \& Kunisawa, 1963). The integral relationship between photopigment synthesis and protein synthesis suggests that control of bacteriochlorophyll formation may be at the genetic level. The role of RNA in mediating synthesis of specific proteins is well known. To gain information about the relationship of protein synthesis to bacteriochlorophyll formation I examined the RNA metabolism of $\boldsymbol{R}$. spheroides under conditions where the organisms were increasing their specific photopigment content.

\section{METHODS}

Organisms. The strains of Rhodopseudomonas spheroides used were strain Ga, and strain $\mathbf{M - 2 5}$ which requires uracil for growth. These bacteria and the methods used to grow them were described previously (Lessie, 1965).

Semi-aerobic incubation of bacteria. Cultures were grown aerobically to a population equivalent to about $100 \mu \mathrm{g}$. protein $/ \mathrm{ml}$. The organisms were centrifuged and suspended to ten times their original concentration in fresh medium, and $60 \mathrm{ml}$. volumes of the suspension were shaken at $34^{\circ}$ in $\perp$-tubes (see Lascelles, 1959).

Determination of cellular nucleic acids, protein, and bacteriochlorophyll. RNA and DNA were extracted from organisms with hot trichloroacetic acid (TCA). RNA was estimated colorimetrically by reaction with orcinol (Schneider, 1945). DNA was estimated by reaction with indole (Ceriotti, 1952). TCA-insoluble protein was digested in $\mathrm{NaOH}$ and estimated by the Folin phenol method (Lowry et al. 1953). The details of these procedures were given elsewhere (Lessie, 1965). Bacteriochlorophyll was extracted from bacteria with methanol, and estimated by measuring the extinction of the methanolic extracts at $775 \mathrm{~m} \mu$ (see Cohen-Bazire et al. 1957).

Incorporation of ${ }^{14} \mathrm{C}$-uracil into bacteria. Uptake of ${ }^{14} \mathrm{C}$-uracil into cellular RNA was measured as follows. Culture samples were diluted $1 / 2$ to $1 / 10$ in cold trichloroacetic acid (TCA) to give a concentration of between 20 and $100 \mu \mathrm{g}$. protein/ ml. in $5 \%$ TCA. Part of the TCA-treated sample (containing about $100 \mu \mathrm{g}$. protein) was filtered through Millipore membranes (0.65 $\mu$ pore size) and the organisms washed with cold $5 \%$ TCA. The membranes were dried, cemented to planchettes, and their radioactivities determined by using a thin window Geiger tube. At the concentration of bacteria used it was unnecessary to correct for self-absorption. In a few experiments ${ }^{14} \mathrm{C}$-labelled RNA was extracted from the bacteria with hot TCA. The results were identical to those obtained using the Millipore technique.

Preparation and characterization of ribosomes and $R N A$. Bacteria were disrupted in a French press to obtain crude extracts containing ribosomes and soluble RNA. Ribosomal RNA was obtained by deproteinizing the crude extracts with sodium lauryl sulphate and phenol. The ribosomes and RNA were characterized by sucrose gradient centrifugation using an SW-39 rotor in a Spinco Model L ultracentrifuge, The detailed procedures followed to obtain and characterize Rhodopseudomonas spheroides ribosomes and RNA have already been reported (Lessie, 1965).

$2-{ }^{14} \mathrm{C}$-uracil was obtained from the Radiochemical Centre Amersham, Buckinghamshire. Millipore filters were obtained from the Millipore Filter Co., Bedford, Mass., U.S.A. 


\section{RESULTS}

Effect of light on the differential rate of RNA synthesis. Cultures of Rhodopseudomonas spheroides subjected to an increase in light intensity temporarily stopped forming photopigments and synthesized RNA preferentially. After the specific RNA content ( $\mu \mathrm{g}$. RNA/ $\mu \mathrm{g}$. protein) increased to the value value characteristic of growth at the higher light intensity increase of RNA proceeded in step with increase of protein. For example a culture of $\boldsymbol{R}$. spheroides strain Ga subjected to a step-up

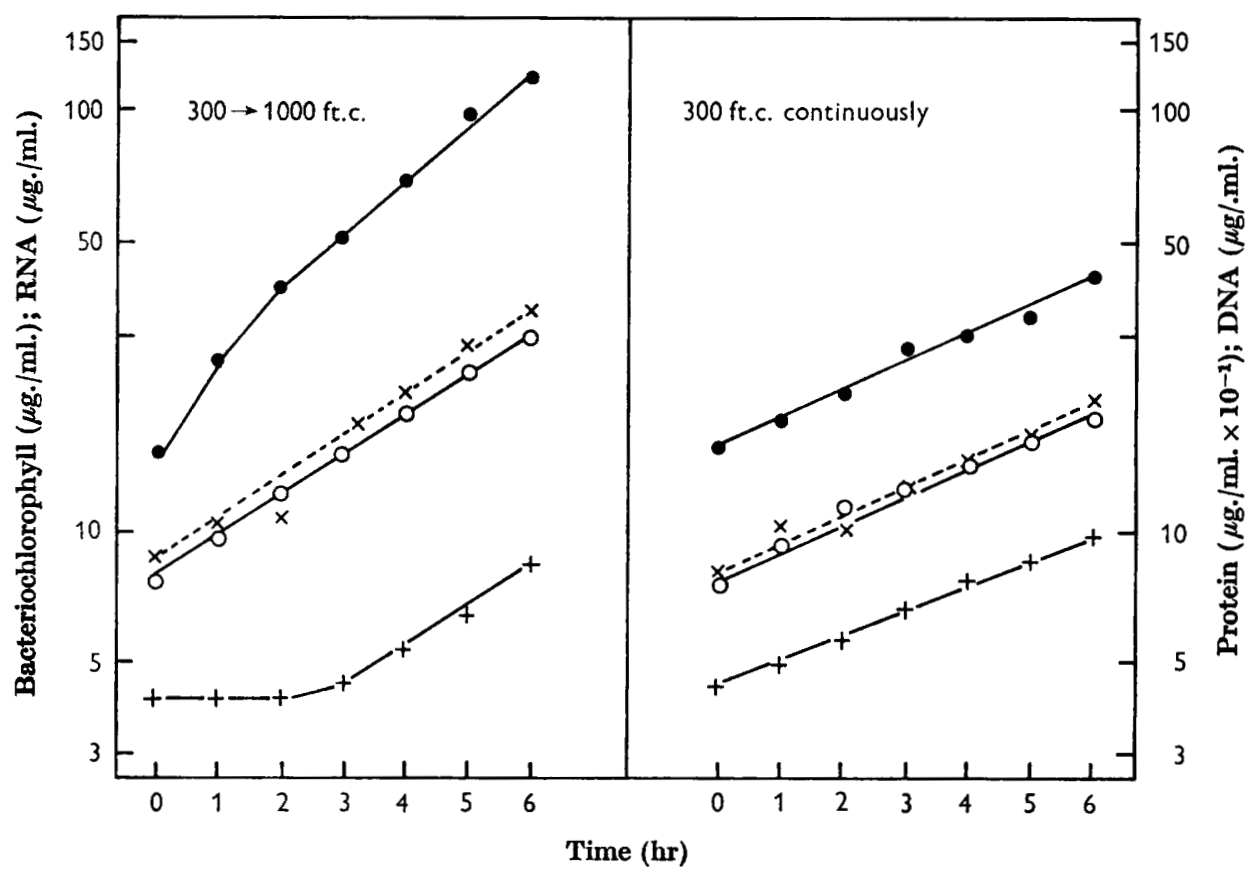

Fig. 1. Increase of specific RNA content following an increase in light intensity. Rhodopseudomonas spheroides Ga was grown in $400 \mathrm{ml}$. SG medium at a light intensity of $300 \mathrm{ft} . c$. The culture was bubbled with a mixture of $5 \%(\mathrm{v} / \mathrm{v}) \mathrm{CO}_{2}$ and $95 \%(\mathrm{v} / \mathrm{v}) \mathrm{N}_{2}$. When the culture reached a concentration equivalent to about $50 \mu \mathrm{g}$. protein $/ \mathrm{ml}$. it was divided into two portions. One portion was incubated as before in light at $300 \mathrm{ft} . c$.; the other portion was incubated in light at $1000 \mathrm{ft}$.c. At the indicated times duplicate samples were taken for determination of bacteriochlorophyll $(+-+)$, protein $(0-0)$, RNA (-) DNA $(x-x)$.

in light intensity from 300 to 1000 foot-candles (ft.c.) synthesized RNA preferentially until its specific RNA content was increased about twofold (from $0 \cdot 13$ to $0 \cdot 25$, see Fig. 1). The amount of DNA/protein remained constant with a specific DNA content of about $\mathbf{0} \cdot \mathbf{1}$.

Conversely, a decrease in light intensity caused the rate of RNA synthesis to decrease below the rate of protein synthesis; as a consequence the cellular RNA was diluted. After the specific RNA content decreased to the value characteristic of growth at the lower light intensity, balanced synthesis of RNA was resumed. Accordingly, a culture subjected to a step-down in light intensity formed bacteriochlorophyll without significantly increasing its net content of RNA. For example, 
following a decrease in light intensity from 1000 to $200 \mathrm{ft} . c$. the specific bacteriochlorophyll content of a culture of Rhodosopeudomonas spheroides strain Ga more than doubled while net increase of RNA was arrested (see Fig. 2). The specific DNA content increased slightly following the step-down in light intensity and then readjusted to its initial value.
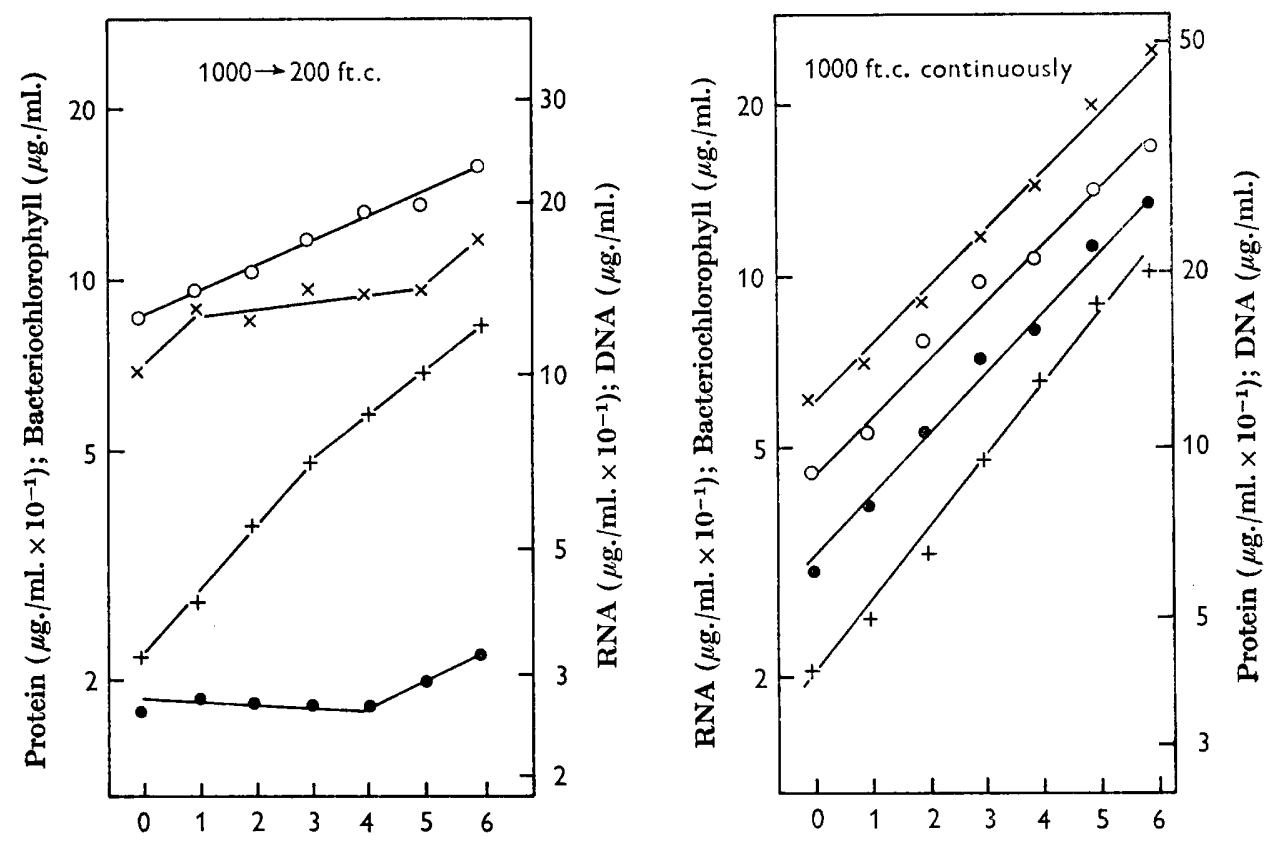

Time (hr)

Fig. 2. Decrease of specific RNA content following a decrease in light intensity. Rhodopseudomonas spheroides was grown in $400 \mathrm{ml}$. SG medium in light at an intensity of $1000 \mathrm{ft} . c$. The culture was bubbled with a mixture of $5 \%(\mathrm{v} / \mathrm{v}) \mathrm{CO}_{2}$ and $95 \%(\mathrm{v} / \mathrm{v}) \mathrm{N}_{2}$. When the culture reached a concentration equivalent to about $50 \mu \mathrm{g}$. protein $/ \mathrm{ml}$. it was divided into two portions. One portion was maintained in $1000 \mathrm{ft} . c$. ; the other was placed in light at $200 \mathrm{ft} . c$. Duplicate samples were taken at specified times for determination of bacteriochlorophyll $(+-+)$, protein $(0--0)$, RNA $\left(0_{-0}\right)$, DNA $(x-x)$.

RNA synthesis following a decrease in light intensity. RNA synthesis was not abolished by a decrease in light intensity. The bacteria incorporated radioactive uracil into their RNA at the same time as they preferentially synthesized bacteriochlorophyll. Figure 3 shows the kinetics of entry of ${ }^{14} \mathrm{C}$-uracil into the cold-TCA insoluble fraction of a culture of Rhodopseudomonas spheroides strain $\mathrm{M-25}$ following a step-down in light intensity from 1200 to $120 \mathrm{ft}$.c. Incorporation which occurred after the initial rapid uptake amounted to about $10 \%$ of that in cultures maintained at $1200 \mathrm{ft} . c$. Following a decrease in light intensity from 1200 to $400 \mathrm{ft} . c$. the rate of uracil incorporation was about $20 \%$ the value at $1200 \mathrm{ft} . c$.

In order to ascertain that under the above conditions uracil was incorporated into RNA and to determine which classes of RNA were being synthesized the following experiments was performed. Cultures of Rhodopseudomonas spheroides $\mathrm{M}-25$ were subjected to a step-down in light intensity from 1200 to $120 \mathrm{ft} . c$., and then given a 
2 min. pulse of ${ }^{14} \mathrm{C}$-uracil which was 'chased' for different times with excess ${ }^{12} \mathrm{C}$ uracil. Phenol purified RNA was prepared from the bacteria, and characterized by sucrose gradient centrifugation. Figure 4 shows the sucrose gradient profiles of RNA from bacteria which were given a 2 min. pulse of ${ }^{14} \mathrm{C}$-uracil, and then incubated for 30 sec. or 2,10 , or $20 \mathrm{~min}$. with an excess of unlabelled uracil. The sedimentation patterns were similar when the bacteria were subjected to a step-down in light

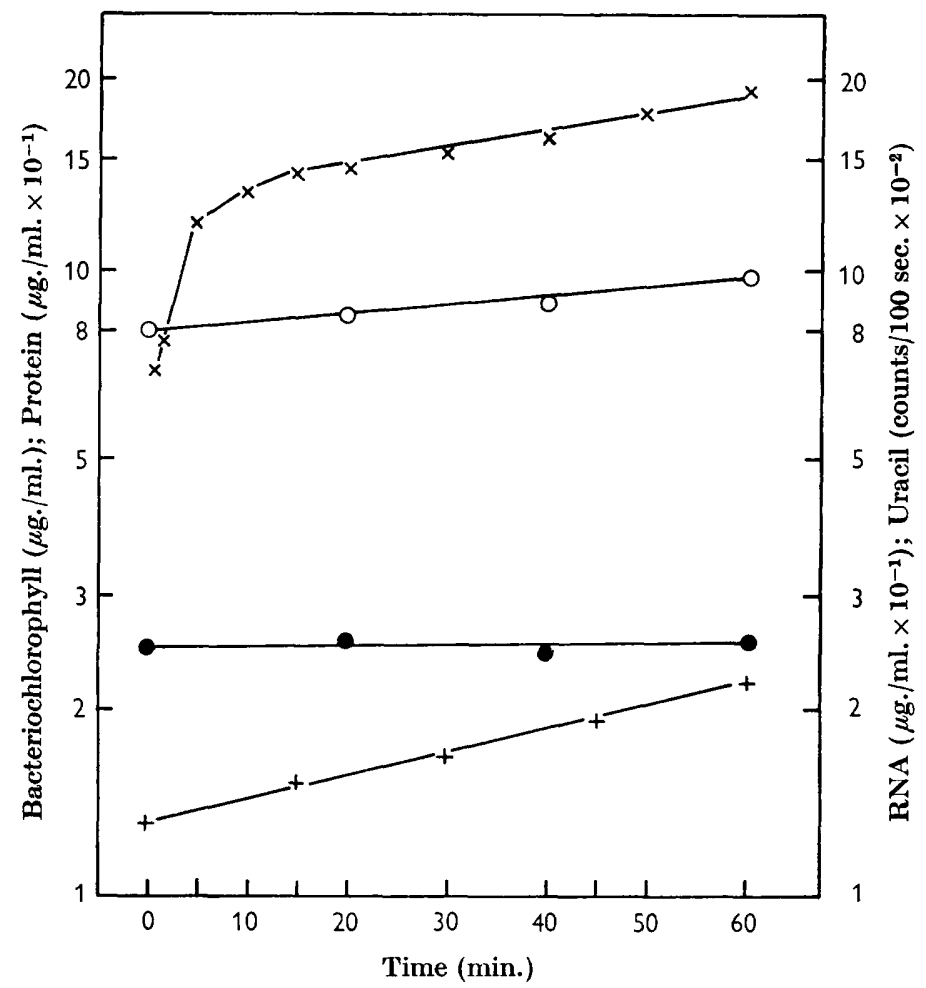

Fig. 3. Uracil incorporation into RNA during preferential bacteriochlorophyll formation under anaerobic conditions. Rhodopseudomonas spheroides $\mathrm{M-25}$ was grown in 1200 ft.c. in $200 \mathrm{ml}$. SG medium containing $5 \mu \mathrm{g}$. uracil $/ \mathrm{ml}$. The culture was bubbled with a mixture of $5 \%(\mathrm{v} / \mathrm{v}) \mathrm{CO}_{2}$ and $95 \%(\mathrm{v} / \mathrm{v}) \mathrm{N}_{2}$. When the cells reached a concentration equivalent to about $100 \mu \mathrm{g}$. protein $/ \mathrm{ml}$. they were centrifuged and suspended in $200 \mathrm{ml}$. SG medium containing $5 \mu \mathrm{g}$. uracil $/ \mathrm{ml}$. and a total of 20 microcuries ${ }^{2-14} \mathrm{C}$-uracil (3730 counts $/ 100 \mathrm{sec} . / \mu \mathrm{g}$. uracil). The suspension was incubated in light at an intensity of 120 ft.c., and gassed as before. At the indicated times samples were removed for determination of bacteriochlorophyll $(+-+)$, RNA (-O), protein (O-O), radioactive uracil in cold-TCA washed cells from $1 \mathrm{ml}$. culture $(x-\times)$.

intensity from 1200 to $400 \mathrm{ft} . c$. or maintained at $1200 \mathrm{ft} . c$. It should be noted that $R$. spheroides is devoid of the usual $23 \mathrm{~S}$ ribosomal RNA (Lessie, 1965). The first RNA to be labelled was unstable and sedimented differently from the bulk ribosomal and soluble RNAs. The sedimentation behaviour of this heterogeneous fraction of RNA was similar to that of m-RNA. Within $10 \mathrm{~min}$. most of the label passed into the stable ribosomal and soluble RNA fractions.

As expected from the kinetics of labelling of phenol-purified RNA, label was found to enter rapidly into the ribonucleoprotein particles of bacteria subjected to a 
decrease in light intensity. Figure 5 shows the kinetics of appearance of ${ }^{14}$-uracil in the $30 \mathrm{~S}$ and $50 \mathrm{~S}$ ribosomes of bacteria which were subjected to a step-down in light intensity from 1200 to $120 \mathrm{ft}$. c. Similar incorporation of label into ribosomes were obtained with bacteria transferred from 1200 to $400 \mathrm{ft} . c$. or bacteria maintained at $1200 \mathrm{ft} . c$. In all three instances the $30 \mathrm{~S}$ ribosomes were labelled more rapidly than were the $50 \mathrm{~S}$ ribosomes.

RNA synthesis in semi-aerobic cultures. Suspensions of aerobically grown Rhodopseudomonas spheroides subjected to a marked decrease in $\mathrm{O}_{2}$ tension formed photopigments without significantly increasing their net content of RNA. The bacteria did, however, continue to incorporate ${ }^{14} \mathrm{C}$-labelled uracil into cellular RNA (see

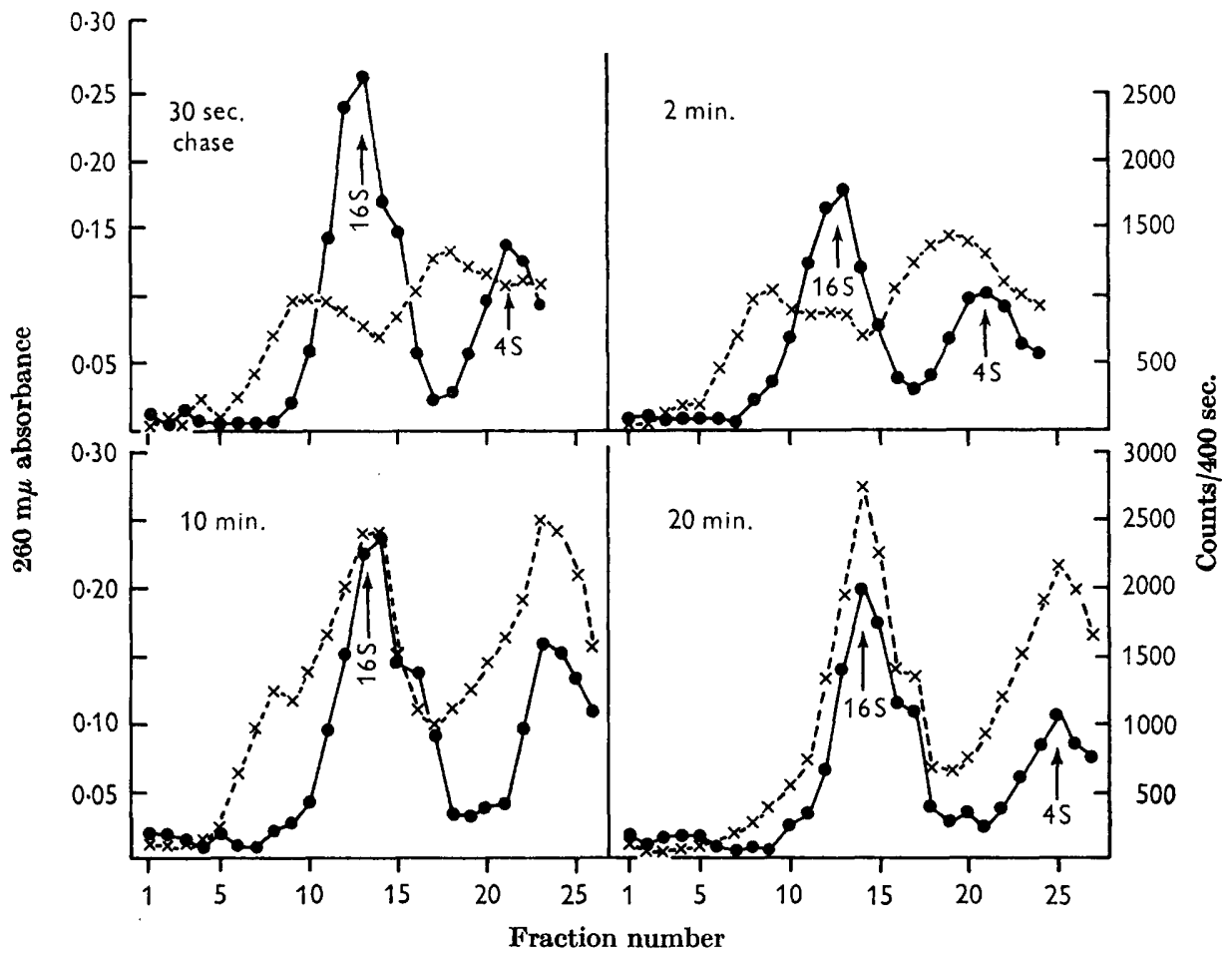

Fig. 4. RNA synthesized following a decrease in light intensity. Rhodopseudomonas spheroides was grown in $1200 \mathrm{ft} . c$. and transferred to $120 \mathrm{ft} . c$. as described in Fig. 3, except that transfer was to medium containing one $\mu \mathrm{g}$. uracil $/ \mathrm{ml}$. and no ${ }^{14} \mathrm{C}$-uracil. After $3 \mathrm{~min} .20 \mu$ c. ${ }^{-14} \mathrm{C}$-uracil were added in one $\mathrm{ml}$. (zero time). Two min. later $3 \cdot 6 \mathrm{ml}$. $10^{-2} \mathrm{M}-12^{12} \mathrm{C}$-uracil were added (final uracil conc. $20 \mu \mathrm{g} . / \mathrm{ml}$.). At $30 \mathrm{sec}$. and at $20 \mathrm{~min}$. $100 \mathrm{ml}$. volumes of culture were poured onto $50 \mathrm{~g}$. crushed ice containing $0.75 \mathrm{ml}$. $2 \times 10^{-1} \mathrm{~m}-\mathrm{NaN}_{3}$. The bacteria were centrifuged, washed twice with cold SG medium containing $10^{-3} \mathrm{M}-\mathrm{NaN}_{3}$, and then frozen. An identical culture was given a two min. pulse of ${ }^{14} \mathrm{C}$-uracil, but the bacteria were sampled, washed, and frozen after $2 \mathrm{~min}$. and after $10 \mathrm{~min}$. chase periods in the presence of excess ${ }^{12} \mathrm{C}$-uracil. Crude ribosome extracts and phenol-purified RNA in $5 \times 10^{-8} \mathrm{M}$-tris buffer $(\mathrm{pH} 7 \cdot 4)$ and $10^{-4} \mathrm{M}-\mathrm{MgCl}_{2}$ were prepared from thawed pulse-labelled bacteria combined with unlabelled bacteria from a $300 \mathrm{ml}$. culture (100 $\mu \mathrm{g}$. protein $/ \mathrm{ml}$.) grown in $1200 \mathrm{ft} . c .0 .2 \mathrm{ml}$. portions of the phenol-purified RNA preparations were centrifuged at 38,000 rev. $/ \mathrm{min}$. for $5 \mathrm{hr}$. through $5 \mathrm{ml} .5-15 \%$ sucrose gradients containing $5 \times 10^{-3} \mathrm{M}$-tris buffer $(\mathrm{pH} \mathrm{7} \cdot 4)$ and $10^{-4} \mathrm{M}_{-} \mathrm{MgCl}_{2}$. The bottoms of the tubes were punctured, and 5 drop fractions were collected. Extinction at $260 \mathrm{~m} \mu$ (O-O) and radioactivities $(x \cdots \times)$ of each sample were determined. 
Fig. 6). Pulse experiments with ${ }^{14} \mathrm{C}$-uracil indicated that, during preferential photopigment synthesis and during the period of adaptation to form photopigments, label was incorporated into ribosomal and soluble RNAs after flowing through unstable RNA like that in Fig. 4.

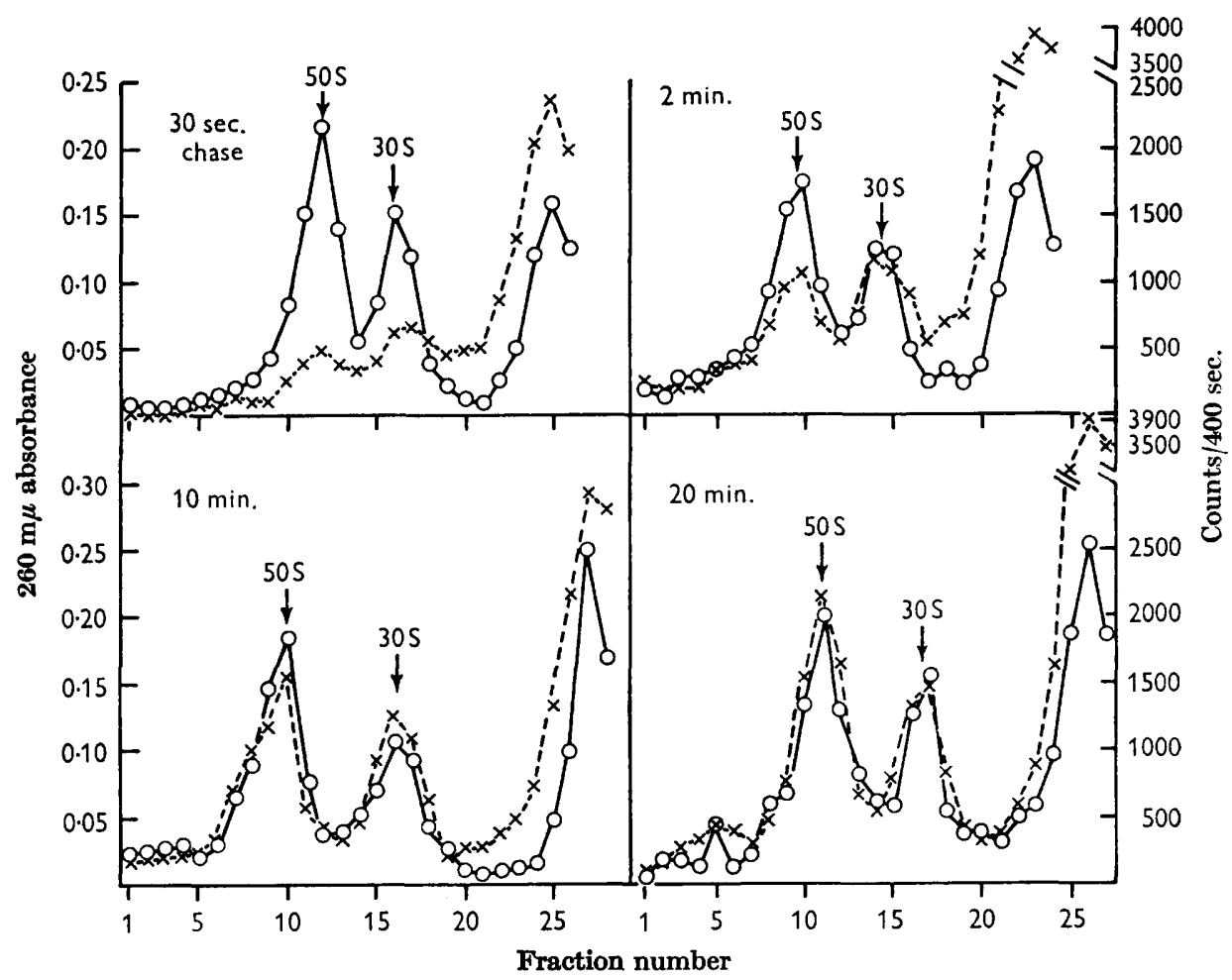

Fig. 5. Synthesis of ribosomes following a decrease in light intensity. $0 \cdot 2 \mathrm{ml}$. samples of the crude ribosome extracts obtained from the samples described in Fig. 4 were centrifuged at 38,000 rev./min. for $2.5 \mathrm{hr}$ through $5-10 \%$ sucrose gradients containing $5 \times 10^{-8}$ M-tris buffer $\left(\mathrm{pH} \mathrm{7.4)}\right.$ and $10^{-4} \mathrm{M}^{-} \mathrm{MgCl}_{2}$. Samples were collected and their radioactivities $(x--\times)$ and $260 \mathrm{~m} \mu$ extinctions $(O-O)$ were determined.

Uracil requirement for bacteriochlorophyll synthesis. Aerobically grown Rhodopseudomonas spheroides incubated semi-aerobically without uracil formed no photopigments, nor did anaerobically grown bacteria deprived of uracil and subjected to a stepdown in light intensity.

\section{DISCUSSION}

The present results indicate that while preferentially synthesizing photopigment Rhodopseudomonas spheroides synthesizes all the usual classes of RNA, although more slowly than during balanced growth. There appears to be no striking change in nucleic acid metabolism (such as a greatly increased output of m-RNA) signalling a preferential rise in bacteriochlorophyll formation. However, the observation that $\boldsymbol{R}$. spheroides strain M-25 did not form bacteriochlorophyll when its RNA synthesis was restricted by deprivation of uracil suggests that RNA synthesis is necessary for bacteriochlorophyll formation. These data are consistent with a role of RNA 
synthesis in bacteriochlorophyll formation as already implied by the results of Sistrom (1963) and Bull \& Lascelles (1963) which established that bacteriochlorophyll formation is coupled to protein synthesis. It is possible that the primary control of photopigment synthesis operates at the genetic level by regulating synthesis of specific informational RNA required to promote synthesis of some protein integrally involved in bacteriochlorophyll synthesis. Our results indicate that if such a control exists detection of the informational RNA involved would depend upon more sensitive technique than sucrose gradient resolution of the entire bacterial complement of RNA.

It has been shown that Rhodopseudomonas spheroides is devoid of the usual $23 \mathrm{~S}$ ribosomal RNA (Lessie, 1965). The experiments reported here show that $R$. spheroides contains unstable RNA which sediments more rapidly than does $16 \mathrm{~S}$

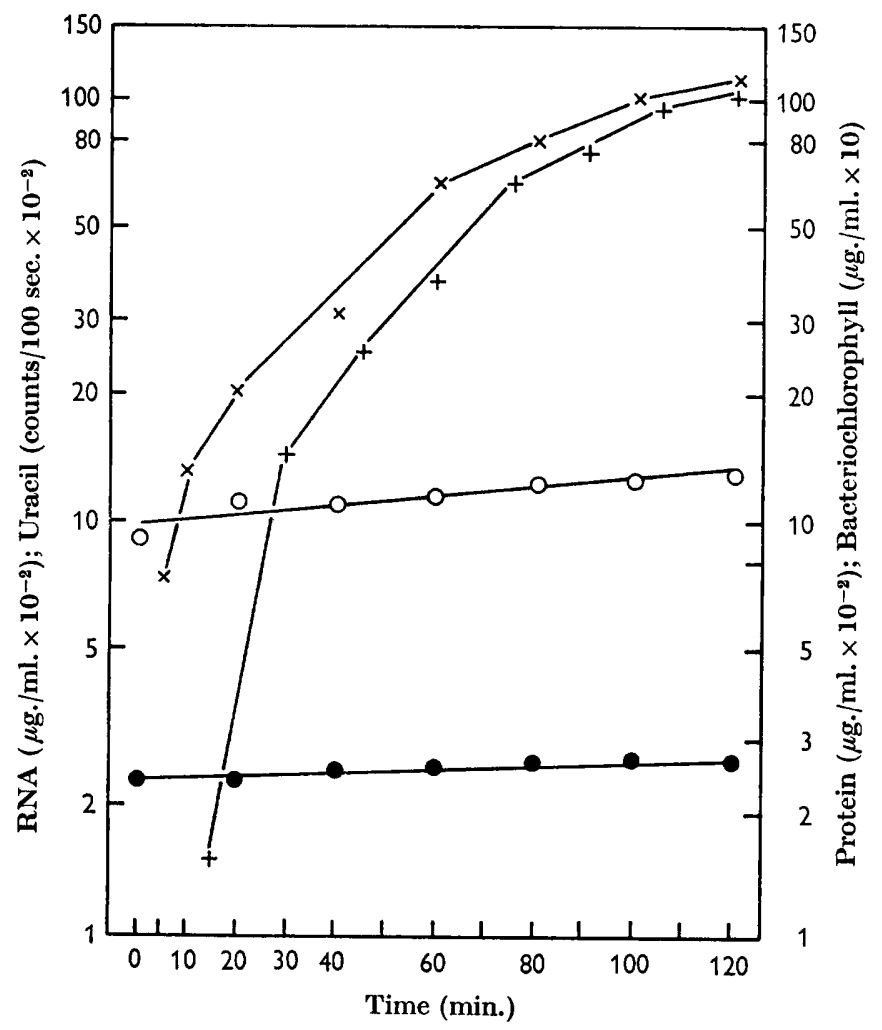

Fig. 6. Uracil incorporation into RNA during semi-aerobic incubation. Rhodopseudomonas spheroides was grown aerobically to a concentration equivalent to about $100 \mu \mathrm{g}$. protein/ml., centrifuged, and suspended to about $1 \mathrm{mg}$. protein $/ \mathrm{ml}$. in SG medium containing $20 \mu \mathrm{g}$. uracil $/ \mathrm{ml}$. Three $65 \mathrm{ml}$. volumes of the suspension were distributed into separate $\perp$-tubes. 20 microcuries $2-{ }^{14} \mathrm{C}$-uracil in one $\mathrm{ml}$. were added to one of the tubes (2210 counts $/ 100$ sec. $/ \mu \mathrm{g}$. uracil). All three tubes were shaken gently at $34^{\circ} \mathrm{C}$. At $15 \mathrm{~min}$. intervals $3 \mathrm{ml}$. samples for bacteriochlorophyll determination were taken alternatively from the two tubes without ${ }^{14} \mathrm{C}$-uracil. At the indicated times $0.5 \mathrm{ml}$. samples of the culture with ${ }^{14} \mathrm{C}$-uracil were pipetted into $4.5 \mathrm{ml}$. cold $5 \%$ TCA. $4 \mathrm{ml}$. of the TCA-treated sample was assayed for RNA and for protein; the remainder was used to determine radioactivity in the cold-TCA insoluble cell fraction. $-O$, RNA; $\bigcirc-O$, protein; +-+ , bacteriochlorophyll; $x-x$, radioactive uracil in cold TCA-washed bacteria from one ml. culture. 
ribosomal RNA. Two observations make it unlikely that this RNA represents a small pool of 23S ribosomal RNA. First, examination of the kinetics of incorporation of labelled uracil into RNA indicated that the RNA under discussion was labelled more rapidly than was $16 \mathrm{~S}$ RNA. Secondly, under the same conditions $30 \mathrm{~S}$ ribosomes were labelled more rapidly that $50 \mathrm{~S}$ ribosomes. Since $16 \mathrm{~S}$ RNA is presumed to comprise the RNA of $30 \mathrm{~S}$ ribosomes, it is unlikely that $16 \mathrm{~S}$ RNA would be labelled more slowly than RNA of $50 \mathrm{~S}$ ribosomes. I presume that the RNA in question was not derived from 50S ribosomes.

I am grateful to Dr June Lascelles for her help and advice during this work. The author is a post-doctoral fellow of the United States Public Health Service. The work was aided by a grant to the Department from the Rockefeller Foundation.

\section{REFERENCES}

Bull, M. J. \& LAScelles, J. (1963). The association of protein synthesis with formation of pigments in some photosynthetic bacteria. Biochem. J. 87, 15.

Ceriotti, G. (1952). A microchemical determination of deoxyribonucleic acid. J. biol. Chem. 198, 297.

Cohen-Bazire, G. \& Kunisawa, R. (1963). The fine structure of Rhodospirillum rubrum. J. cell. Biol. 16, 401.

Cohen-Bazire, G., Sxstrom, W. R. \& Stanier, R. Y. (1957). Kinetic studies of pigment synthesis by non-sulphur purple bacteria. J. cell. comp. Physiol. 49, 25.

Gibson, K. D., Neuberger, A. \& Tart, G. H. (1963). Studies on the biosynthesis of porphyrin and bacteriochlorophyll by Rhodopseudomonas spheroides 4 . S-adenosylmethionine magnesium protoporphyrin methyl transferase. Biochem. $J .88,325$.

LASCELuES, J. (1959). Adaptation to form bacteriochlorophyll in Rhodopseudomonas spheroides : changes in activity of enzymes concerned in pyrrole synthesis. Biochem. $J$. 72, 508.

LEssie, T. G. (1965). The atypical ribosomal RNA complement of Rhodopseudomonas spheroides. J. gen. Microbiol. 39, 311.

Lowry, O. H., Rosebrough, N. J., Farn, A. L. \& Randall, R. J. (1951). Protein measurement with the Folin phenol reagent. J. biol. Chem. 193, 265.

Schneider, W. C. (1945). Phosphorous compounds in animal tissues. 1. Extraction and estimation of desoxypentose nucleic acid and of pentose nucleic acid. J. biol. Chem. 161, 293.

Sistrom, W. R. (1963). Observations on the relationship between formation of photopigments and the synthesis of protein in Rhodopseudomonas spheroides. J. gen. Microbiol. 28, 599. 